\title{
Impact of Rule Governance Mechanism on Project Performance in Public Rental Housing PPP Projects: Control Rights as a Moderating Variable
}

\author{
Dan Liu $(\mathbb{D}$, Wenfeng Mo $\mathbb{D}$, and Chuanbin Yin $(\mathbb{1}$ \\ School of Tourism and Urban Management, Jiangxi University of Finance and Economics, Nanchang 330013, China \\ Correspondence should be addressed to Dan Liu; dandan811023@163.com and Chuanbin Yin; yinchuanbin@jxufe.edu.cn
}

Received 26 February 2021; Accepted 4 May 2021; Published 28 May 2021

Academic Editor: Paolo Renna

Copyright ( 2021 Dan Liu et al. This is an open access article distributed under the Creative Commons Attribution License, which permits unrestricted use, distribution, and reproduction in any medium, provided the original work is properly cited.

\begin{abstract}
Exploring the relationship among rule governance mechanism, project control rights allocation, and project performance in public-private partnership (PPP) projects is of great significance for optimizing control rights allocation and governance mechanism to improve project performance of PPP projects. Previous studies have mainly focused on the impact of contractual governance or rule-based governance on the performance of PPP projects, and the research on the allocation of project control rights into the analysis framework is insufficient. The goal of this study is to explore the moderating effect of the allocation of project control rights on the project's rule mechanism affecting project performance. Based on the theoretical analysis and literature review, three hypotheses are put forward, and the hypotheses are tested by structural equation model using the large sample data collected by questionnaire survey. This study shows that both the rule governance mechanism and project control right allocation have a positive impact on project performance, and the allocation of project control right has a negative moderating effect on the impact of rule governance mechanism on project performance. The public characteristics of PPP projects determine that it is inappropriate for social capital to have too much project control rights. The degree of project control rights owned by social capital should be balanced with the rule governance in the dynamic management process.
\end{abstract}

\section{Introduction}

With the continuous acceleration of urbanization, there are varying degrees of housing difficulties for relatively lowincome groups due to the increasing urban floating population around the world. In order to solve such problems, a series of housing security plans have been launched in different countries and regions [1,2], such as the public rental housing $(\mathrm{PRH})$ scheme launched by the Chinese Government in 2014 [3]. However, due to the lack of professional knowledge and experience in operation and management related to public housing in most countries, operation models of public sectors are often extensive and resource allocation efficiency is low, leading to the failure of public housing projects in the implementation process [4]. In order to improve the construction quality and operation efficiency of public rental housing and relieve the financial pressure of the government, governments of various countries began to introduce PPP mode into the construction of public housing [4-6]. However, since the private sector aims at maximizing profits [7], the private sector may have self-interested investment behavior in the process of cooperation, focusing only on the realization of its own interests and ignoring the common interests. In addition, the different participation of project participants in the project will cause information asymmetry among project stakeholders, which will further aggravate the occurrence of moral hazard and opportunistic behavior in the private sector [8]. These factors will reduce the cooperation efficiency of the organization and aggravates the possibility of project failure.

Recent research demonstrates that rule governance can coordinate the contractual relationship between the public sector and the private sector, inhibit the occurrence of 
opportunistic behavior, and improve the cooperative surplus. In PRH PPP projects, rule governance refers to a series of institutional arrangements that reduce transaction costs and improve cooperation efficiency throughout the life cycle of the project. It guarantees the success of the project by stipulating the project benefit distribution scheme, project investment and financing structure, project performance evaluation scheme, and so on. As the core of the project governance structure, the allocation of project control right is closely related to the project risk sharing and reward incentive mechanism [9], which also makes the rule governance mechanism under different control allocation schemes have different effects on project performance [10]. Therefore, the regulatory role of project control right should be considered in the impact of rule governance mechanism on project performance.

However, the research on control rights of PPP projects mostly focuses on discussing the allocation of control rights based on incomplete contract theory [10], which has not revealed the mechanism of action of PPP project company's control right allocation on project rule governance. In view of this, from the perspective of rule governance, the research builds a model between rule governance, control rights allocation and project performance in PRH PPP projects and explores the path of rule governance on project performance. The main aim is to provide theoretical guidance for the government to formulate appropriate control countermeasures and thus to promote the healthy development of affordable housing. The results of this study are also applicable to the construction of public rental housing projects in other regions of the world and could be used for reference in other forms of affordable housing projects. The organization of this article is as follows. It starts off with a literature review in related fields and the introduction of the relevant theories of PPP governance, which is followed by a series of hypotheses. Then, the research approaches used in the study are presented and the proposed hypotheses are tested using a questionnaire survey. Finally, the study finishes with a discussion and a conclusion.

\section{Theoretical Model and Research Hypothesis}

\subsection{Conceptual Framework}

2.1.1. Rule Governance Mechanism. Contract is the most important carrier of rule governance, so research on rule governance focuses on contract governance and generally emphasizes that the responsibilities and obligations of each participant should be clarified through formal written contracts. Some scholars also believe that restricting rule governance to contract governance greatly weakens the effect of rule governance and is not conducive to improve project performance [11]. This paper believes that PPP projects belong to a full life cycle operation, and the output quality of the previous stage directly affects the cost control of the next stage. Hence, the governance of PPP project rules should include a series of institutional arrangements for reducing costs and increasing efficiency formed during the entire life cycle of the project.
In the decision-making stage of the project, the government departments mainly conduct feasibility demonstrations of economic, social, environmental, and other aspects of the project investment opportunities through feasibility studies and project proposals and choose the most suitable project from numerous project opportunities. Choosing the right project is one of the key factors for the success of a PPP project. The future economic feasibility and financial status of the project will affect the willingness of the private sector to participate in PPP projects and the performance behavior of future cooperation and then affect the overall performance of the project. Therefore, through the control of the key control nodes in the project selection link, we can avoid the development of bad projects, realize the survival of the fittest, and increase the possibility of project success. After the approval of the implementation plan, it is necessary to conduct social capital bidding. It is generally believed that the transparent bidding mechanism is not only conducive to improve the enthusiasm of social capital participation and ensure the quality of social capital participation [12] but also can use the cost of bidding mechanism to discover functions, reduce project transaction costs, and thus improve project performance [13]. After the partner is determined, it will enter the implementation stage, which mainly focuses on three aspects from the perspective of contract governance: risk sharing, income distribution, and project supervision. Among them, risk sharing and cooperation surplus sharing are essential to the success of PPP projects. A large amount of literature described how to allocate risk between the government and the private sector $[14,15]$.

In addition, according to the "Government and Social Capital Cooperation Model Operation Guide" (Caijin [2014] No. 113) issued by the Ministry of Finance of the People's Republic of China in 2015 [16], the operation process of the PPP project is divided into 5 stages, and each stage corresponds to a number of core achievements. The specific content is shown in Figure 1. From the operation process and corresponding core documents of PPP projects, it can be seen that there are four rule governance mechanisms in the whole life cycle of PPP projects, namely, project selection mechanism, bidding mechanism, risk-return mechanism and project supervision mechanism. Through the highquality governance of core achievements, project performance can be improved and project success can be promoted.

Therefore, rule governance is the basis of establishing the relationship between all parties, covering the project selection mechanism, bidding mechanism, risk-return mechanism, and project supervision mechanism from project identification to project handover.

(1) Project Selection Mechanism. The function of the project selection mechanism is to screen out public rental housing projects suitable for the PPP model, which mainly involves the government's evaluation of the feasibility study report, value for money report, financial affordability report, and implementation plan. In addition, the government should carefully demonstrate the social cost of the project, the 


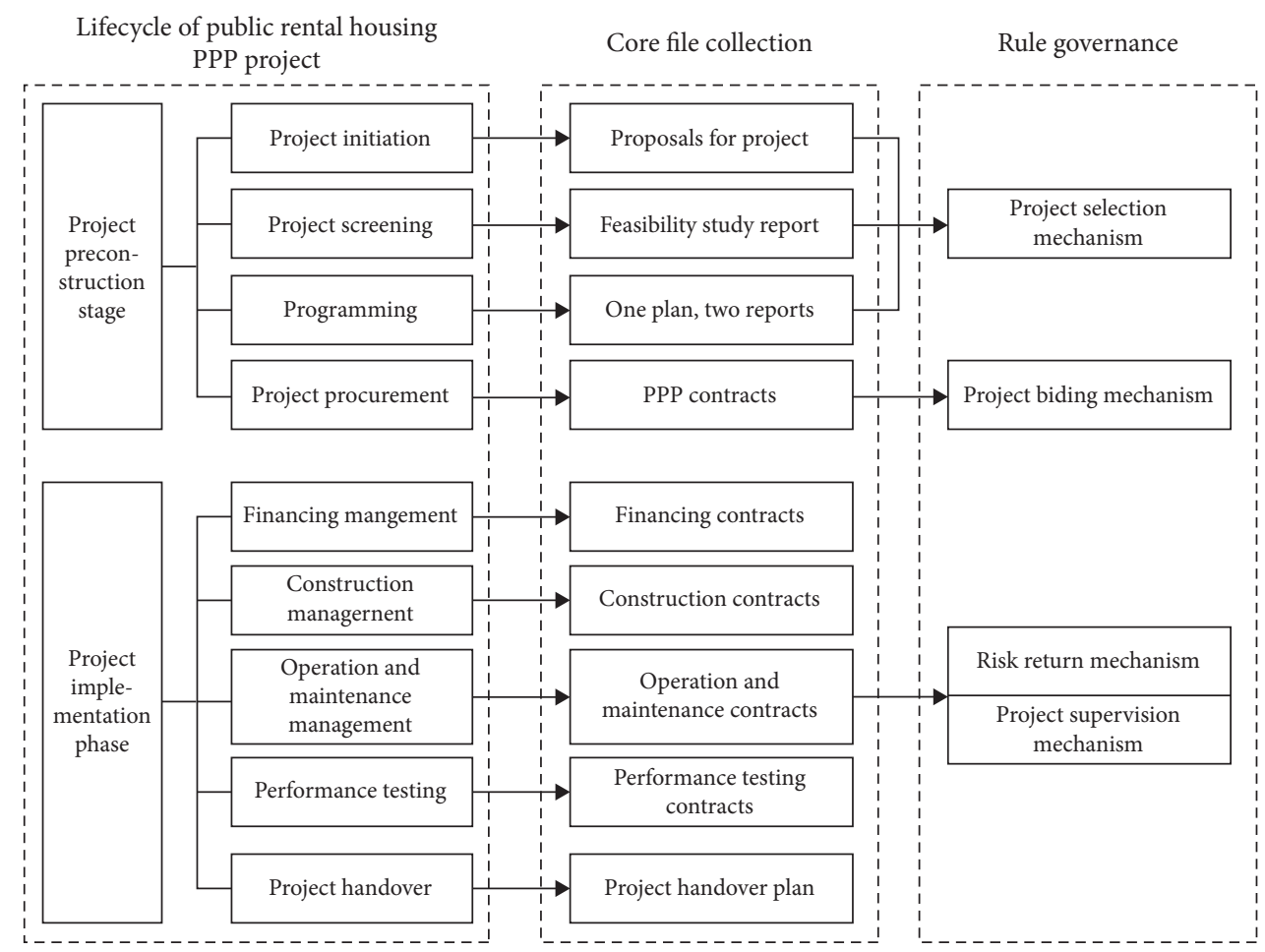

FIgURE 1: Content structure of rule governance of public rental housing PPP project.

affordability of the public, and the possible PPP pattern. Through literature review, theoretical analysis, and expert interviews, the key control nodes of project selection stage are obtained, including standardized project selection procedure, scientific project evaluation, efficient project decision-making, reasonable and feasible consultation report, and long-term demand stability demonstration of the project. Based on the above key nodes, the measurement indicators of project selection mechanism include fairness of prior process, scientificity of evaluation process, efficiency of in-process decision-making, feasibility of consulting scheme, practicality of policy support, and correctness of project selection.

(2) Project Bidding Mechanism. After the approval of the implementation plan, social capital bidding is needed. The function of this mechanism is to select the best bidder through reasonable competition. According to the "Government and Social Capital Cooperation Model Operation Guide" (Caijin [2014] No. 113) [16] and the "Administrative Measures for Government Procurement of Government and Social Capital Cooperation Projects" (Caiku [2014] No. 215) [17] issued by the Ministry of Finance of the People's Republic of China, the procurement process of social capital in PPP projects can be roughly divided into four steps: prequalification, preparation and review of procurement documents, confirmation of procurement results, and contract negotiation. Based on the key control nodes of the procurement process mentioned above, the measurement indexes of the bidding mechanism include compliance of procurement procedures, fairness of procurement review, standardization of procurement documents, rationality of procurement standards, competitiveness of procurement methods, and effectiveness of government supervision.

(3) Risk-Return Mechanism. After the bidding, it entered the implementation stage, which mainly focused on three aspects from the level of rule governance: risk sharing, income distribution, and project supervision. Risk sharing is a dynamic and complex process that is closely related to the contract. The contract structure of the project determines the basic structure of risk sharing and management. Therefore, the measurement of risk sharing is determined by the PPP contract guidelines issued by the Ministry of Finance of the People's Republic of China. Income distribution is a factor affecting whether the public and private parties can sign a contract and the project performance. However, due to the diverse profit models of projects, no specific measurement is involved. Therefore, the survey index and measurement items are arranged and set according to the interview and determined after professional discussion. Considering that the key to risk allocation is to adhere to the principle of riskbenefit equivalence, the allocation of risk mechanism and income mechanism is combined into risk-return mechanism. Specifically, the measurement indicators of risk-return mechanism include rationality of risk sharing, completeness of risk response, rationality of reward scheme, effectiveness of reward mechanism, symmetry of risk-return mechanism, and rationality of reward mechanism.

(4) Project Supervision Mechanism. As the initiator of public rental housing projects, the government effectively protects the public interest by approving and supervising the key control contents in the operation of the project. Specifically, 
the supervision mechanism can be divided into three levels: the first level is the project company's management of the project; the second level is the government's regulation of the project; the third level is the social supervision of the government's regulation behavior and Special Purpose Vehicle (SPV) behavior. Considering that both SPV and contractor are stakeholders of social capital, there are convergence of interests, high degree of public dispersion, and limited specialty. Hence, the project supervision is mainly the government regulation of the project, including the supervision to the project cost supervision, project quality, and the project company operation. The measurement indicators of the project supervision mechanism consist of the clarity of the regulatory body, the rationality of the regulatory indicators, the effectiveness of public participation, the rationality of punishment, the openness of the evaluation results, and the effectiveness of the incentive mechanism.

2.1.2. Allocation of Control Rights. As for the connotation of control right, the classical explanation comes from incomplete contract theory, which considers that control right is the core of ownership and defines residual control right as enterprise ownership directly. Hart and Moore [18] believes that corporate control includes specific control and residual control, the latter of which is those that are not clearly stipulated in the contract. Grossman and Hart [19] demonstrated that the control right under the incomplete contract was a residual control right, that is, the right to decide how the item is used when an unexpected situation occurs. Faccio and Lang [20] believe that the control right is the exclusive dominance over the business operation and decision-making of an enterprise. In $\mathrm{PRH}$ PPP projects carried out in developing countries such as China, the public and private sectors usually jointly provide public products and services through the establishment of project companies [21]. As a result, the control rights of the PRH PPP projects are the corporate control rights based on resources. Sun et al. [22] believe that PPP project control rights are the collection of control rights of all parties involved in the project over the resources invested to achieve maximum benefits, including substantial control rights and residual control rights. Zhang et al. [23] agree that the reasonable allocation of residual control rights is the key to the landing and success of PPP projects.

Referring to the above views, in this study, the control right of PPP project is the institutional arrangement of the allocation of decision-making rights and income rights of the participants in the PPP contract set. Through this institutional arrangement, all partners can standardize the relationship of project responsibilities and rights, reduce conflicts, and maximize project performance. The control rights of PPP projects include specific control rights and residual control rights. The specific control right is a static control right, determined by the shareholding structure. During the operation of PPP projects, the equity structure generally does not change after the determination, and the timing of the allocation of control rights occurs in the early stage of the project. However, the public attributes of PPP projects inhibit the social capital from obtaining huge profits, which leads to the dynamic change of residual rights allocation. The allocation time point of residual control rights mainly occurs in the execution period. Therefore, according to the role of control rights in public rental housing PPP projects, the allocation of project control rights can be divided into two stages. The first stage is the project decision-making stage. In this stage, the allocation of control rights takes place before the establishment of the project company, and the subjects of control right allocation are government and social capital. In the decision-making stage, the government plays a more important role as a manager in the social public sphere, and the form of control power is mainly decision-making power. Deng [24] believes that there are five forms of decision-making according to the degree of social capital participation in decision-making, including individual decision-making right, shared decision-making rights, consultation rights of missile usage, suggestion rights, and execution rights. The second stage is the project implementation stage. The allocation of control rights occurs after the establishment of the project company. The main body of control allocation is the internal investors of the project company. At this stage, the government is one of the shareholders of the project company. The control right is the shareholder power. The shareholder power includes property rights and management participation rights [25]. Property rights are mainly embodied in asset income rights (dividend rights) and capital income rights (exit rights) [25]. The right to participate in management can be refined into the right to operate and the right to assign [25]. Property rights are the core, and the right to participate in management is the guarantee for the realization of shareholder property rights [25].

Based on the above analysis, the allocation of control rights for public rental housing PPP projects can be analysed from five aspects: decision-making rights, dividend rights, exit rights, management rights, and assignment rights.

2.1.3. Project Performance. For performance, scholars and experts have different definitions and induction. In terms of the form of performance, there are mainly three views: performance behavior view [26], performance outcome view [27], and performance behavior-outcome view [28]. Among them, it is generally accepted that performance equals the synthesis of process and result. According to the performance behavior result view, if the performance only focuses on behavior, the behavior may be short-term and lacks longterm planning, then the final result may not be realized; if the performance only focuses on the result, the necessity of behavior process, monitoring, and guidance may be ignored, which is not conducive to team cooperation, organizational coordination, and reasonable allocation of resources [29]. Therefore, from a practical point of view, a good performance should include behavior, output, and result; that is, performance not only includes the relationship between efficiency output and input but also includes the degree of effort to achieve the goal and the degree to achieve the goal. 
Based on the above understanding, there are also two views on the definition of project performance in academic circles. One view is that project performance is a dynamic concept, including process performance and result performance. Leu and Lin [30] believe that project performance is the output and result formed in the process of project construction and implementation. Another point of view is that project performance should include the daily behaviors of project employees and should be defined from the perspective of behaviors related to the effective realization of project objectives. Kagioglou et al. [31] believe that project performance should not only include work output but also pay attention to relevant behaviors of employees in achieving organizational goals. Project performance is closely related to project success. Yuan believes that performance is a tool to measure whether a project is successful and is a concrete manifestation of the standard of project success [32]. The achievement of project performance is critical to project success. On the other hand, the essential feature of PPP projects is that the government provides public services. However, the mode of provision is changed from the direct provision by the government to the production led by social capital, and the government pays for performance; that is, the government and social capital cooperate to provide public goods or services. Therefore, the PPP project performance should not only consider the standard and specific embodiment of project success but also consider the recognition degree of service objects, including the satisfaction of organization members and the public. Based on the above discussion, it is concluded that PPP project performance refers to the realization degree of value for money in the whole life cycle of the project, including the achievement of the initial goal of the project and the realization of the project value, covering project construction performance, project operation and maintenance performance, and customer satisfaction.

\subsection{Research Hypothesis}

2.2.1. Rule Governance Mechanism and Project Performance. Mainstream opinions regard that good rule governance can have a positive effect on project performance. According to Williamson [10], formal contracts can improve project performance by influencing the level of specific investment. Roehrich and Lewis [33] believe that under strict legal provisions and normative standards, contracts can constrain the behavior of parties to ensure project performance. Cao and Lumineau [34] believe that contract governance, as a formal governance mechanism, is an important way and means to curb opportunism, which is crucial to safeguarding the interests of contract subjects and promoting the success of projects. Some scholars also believe that strictly controlled contract terms will inhibit the good cooperation will of trading partners and reduce the positive behaviors of the other party [35]. At the same time, overly strict formal contracts mean distrust or hostility towards trading partners [36], which will have a negative impact on cooperation.

Based on literature analysis and the above discussion, the research hypothesis is proposed:
H1: Rule governance mechanism has a positive effect on project performance.

2.2.2. Control Rights and Project Performance. As for the function of the allocation of control rights, the academia has carried out extensive discussions from different perspectives: firstly, the importance of the allocation of control rights has been studied. The research on contract governance structure is mainly based on the three theories of incomplete contract theory, property right theory, and principal-agent theory, through which it is proved that the reasonable allocation of control rights significantly affects the success of the project [37]. Zhang [38] and Salman et al. [39] all believe that the allocation of control rights is the driving factor for the success or survival of BOT projects. The second is to propose a series of theories around the distribution of residual control rights between the public and private sectors, such as the BG theory proposed by Besley and Ghatak [40] and the FM theory proposed by Francesconi and Muthoo [41]. The third is to use different methods to quantitatively analyse the relationship between control rights and project performance. Alonso-Conde et al. [42] analysed how the public sector grants private companies some rights while enabling private companies to obtain acceptable profits, thereby encouraging the private sector and improving its cooperation efficiency. Zhang et al. [37] established a mathematical model to verify that when an enterprise has self-interested investment, giving different degrees of control shares to the public or private sectors under different parameters can improve the PPP cooperation efficiency. According to Zhang et al. [43], the allocation of control rights has always been the focus of negotiations between the government and the project company in PPP projects, and it directly affects the decision-making behavior and cooperation efficiency of the public and private parties.

Based on literature analysis and the above discussion, the research hypothesis is proposed:

$\mathrm{H} 2$ : Reasonable allocation of control rights has a positive effect on project performance.

2.2.3. Control Rights, Rule Governance, and Project Performance. Different from other projects, PPP project has a long cooperation period, which can be understood as a repeated game process between public and private parties. Hart and Moore believed that repetitive game is an effective cooperation mechanism to promote contracting, but this cooperation mechanism cannot effectively govern various future probable events, which requires the company to have the "distribution of residual control rights," and then this power becomes a supplementary mechanism under the framework of long-term cooperative relationship [18]. Lam et al. [44] believed that project rights and responsibilities should match each other, the allocation of control rights should be consistent with risk sharing, and the party with control rights should bear appropriate risks. Cheng and Chen [45] found that reasonable allocation of control rights was conducive to the relationship governance among cooperative organizations, thereby reducing the occurrence of 
relationship risks. Li et al. [9] believe that the multilayer principal-agent public-private partnership, the natural incompleteness of contracts, and the complexity of the social environment in which the project is located make it insufficient to only emphasize contract governance, and that relationship governance and allocation of control rights can synergistic improve the performance of PPP projects. This paper believes that the public rental housing PPP project contract set is a typical incomplete contract. When the contract is not complete, the conflict of interests between the parties cannot be resolved in advance, and the allocation of residual control rights becomes a key issue. At the same time, the PPP project of public rental housing has a long cooperation period. The introduction of contract governance mechanism can make the research of contract governance structure from static analysis to dynamic analysis, which is more in line with the actual situation of the project.

Based on literature analysis and the above discussion, the research hypothesis is proposed:

H3: Reasonable allocation of control right has a positive mediating effect on the relationship between the rule governance mechanism and project performance.

\section{Research Methods}

3.1. Moderating Effect Analysis Model. Through theoretical analysis, we propose the hypothesis that project control right plays a moderating role in the impact of rule governance mechanism on project performance. Hence, project control right is introduced as a moderator variable. According to Baron and Kenny [46], the moderating variable refers to the variable that affects the direction or strength the relationship between independent variable and dependent variable. It can be classified variable or continuous variable. The basic model of moderating effect analysis is shown in Figure 2, where Predictor is the independent variable, Moderator is the moderating variable, Outcome Variable is the dependent variable, and Predictor X Moderator is the product term of the independent variable and the moderating variable, which also becomes the interaction term. Predictor X Moderator is the product term of the independent variable and the moderator variable and also becomes the interactive term. As a new variable, Predictor X Moderator can be used to judge the regulatory effect by examining its effect on the dependent variable. If the coefficient of its path $\mathrm{C}$ is significant, the regulatory effect exists [46].

It is necessary to choose the corresponding analysis method according to the type of variables to analyse the regulatory effect. The project performance variables, project control variables, and rule governance variables involved in this study are all latent variables, and the structural equation model should also be used to analyse the moderating effect of latent variables. For the structural equation analysis of the interactive effects of latent variables, there are a variety of analysis methods, mainly the distribution-analytic approaches and the product-indicator approaches. The product-indicator approaches are divided into constrained approach and unconstrained approach, and the distributionanalytic approaches include the Latent Moderated Structural

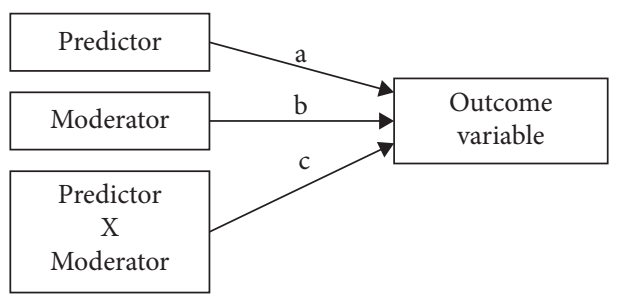

FIgURE 2: Regulatory effect analysis model.

Equations (LMS) approach and the Quasi-Maximum Likelihood (QML) approach [47]. Combining the characteristics of various methods, this study uses the LMS method to analyse the regulatory effect of project control.

3.2. Structural Equation Model. Structural equation model (SEM) is an important statistical method for quantitative research in the field of contemporary behavior and society. It combines the statistical techniques of "factor analysis" and "linear model regression analysis" in traditional multivariate statistical analysis and can be used for model identification, estimation and verification of various causal models [48]. Structural equation model is basically a confirmatory statistical method, which establishes a causal model on the basis of a certain theory or rule of thumb for verification. Compared with traditional statistical analysis methods, structural equation model can simultaneously estimate the measurement indicators and latent variables in the model. Based on theoretical analysis and experience, we put forward hypotheses on the complex relationship between project rule governance mechanism, project control rights, and project performance. These core variables involved in this study are also latent variables. Therefore, the structural equation model is used to conduct a confirmatory analysis on the relationship between the latent variables. In the analysis of structural equation model, Mpuls software is used to process the data and model.

\section{Variable Measurement Method and Data Collection}

4.1. Variable Measurement Method. We collected the firsthand data needed for the study through questionnaire survey. According to the analysis of the concept connotation and measurement of rule governance mechanism and its submechanism, project control right, and project performance, the questionnaire is designed. We distributed questionnaires to 30 experts for a trial survey, then revised some questions according to the experts' suggestions, and finally determined the questionnaire used in this study. The main items of variables measurement in the final questionnaire are shown in Table 1, which clearly reflects how to measure each variable.

4.2. Data Collection. In order to measure variables, this study adopted a questionnaire survey method to collect data. The measurement items of all variables in this study were designed using a five-point Likert scale, from 1 (strongly 
TABLE 1: Variable measures and questionnaire items.

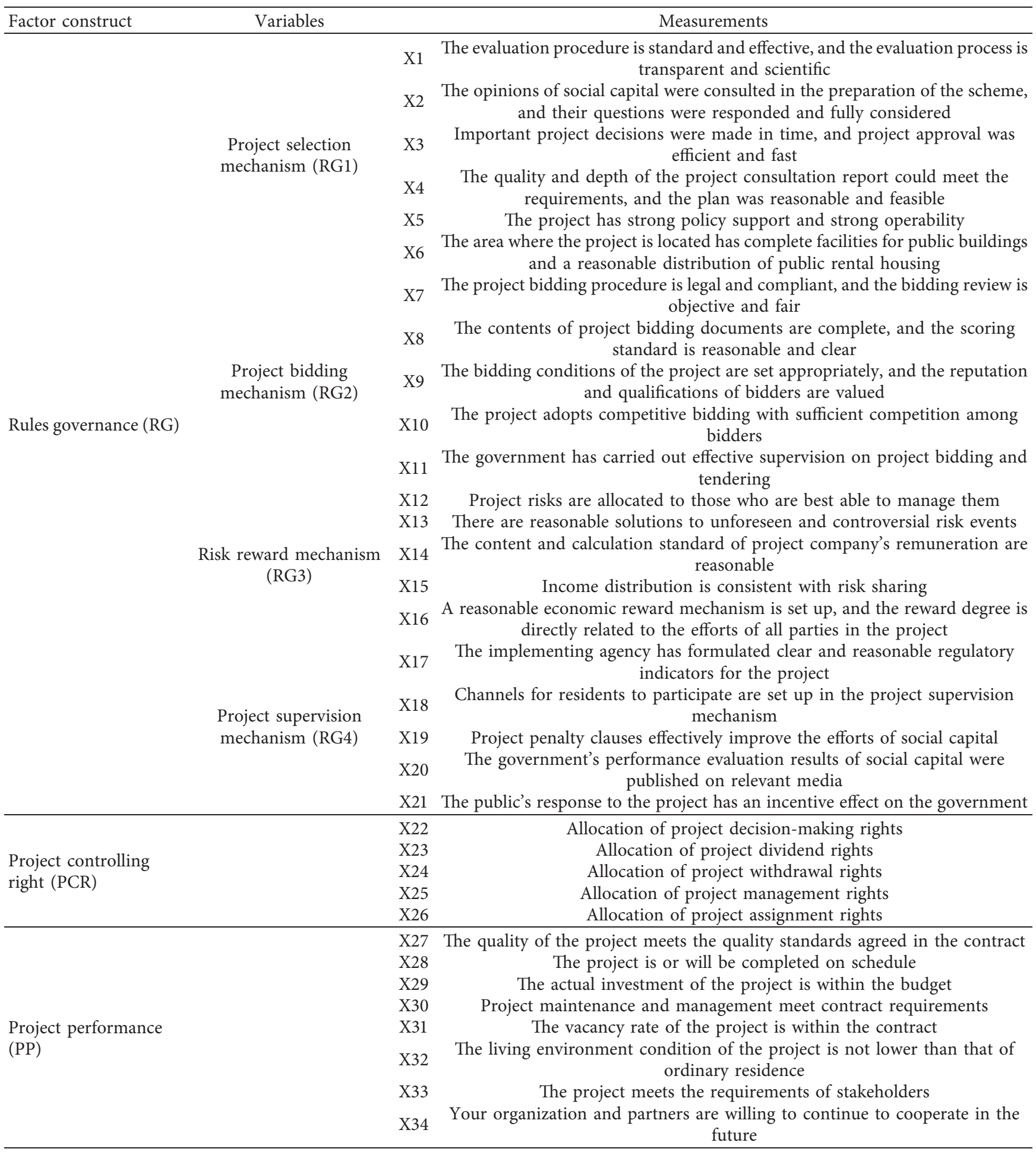

disagree) to 5 (strongly agree). The questionnaire was distributed by network and on site. Through online social platforms, mainly WeChat, 200 online questionnaires were distributed. The on-site distribution mainly utilizes personal network resources, supplemented by the point-to-point distribution of resources from the practical teaching bases of Jiangxi University of Finance and Economics in various regions, and a total of 256 copies are distributed. In 2017 and 2018, the authors used the summer and winter vacations to conduct face-to-face communication and questionnaire distribution to selected interview sites. The reason for selecting multiple different time points for visits is to take into account the phase characteristics of the PPP project and to make the project research process more reliable, which 
TABLE 2: Results of validity and reliability of latent variables.

\begin{tabular}{|c|c|c|c|c|c|}
\hline Latent variable & Items & Standard factor loading (SFL) & $\mathrm{KMO}$ & AVE. & Cronbach's $\alpha$ \\
\hline \multirow{6}{*}{ Project selection mechanism (RG1) } & $\mathrm{X} 1$ & 0.606 & \multirow{6}{*}{0.849} & \multirow{6}{*}{0.576} & \multirow{6}{*}{0.815} \\
\hline & $\mathrm{X} 2$ & 0.690 & & & \\
\hline & $\mathrm{X} 3$ & 0.641 & & & \\
\hline & $\mathrm{X} 4$ & 0.664 & & & \\
\hline & $\mathrm{X} 5$ & 0.630 & & & \\
\hline & $\mathrm{X} 6$ & 0.703 & & & \\
\hline \multirow{5}{*}{ Project bidding mechanism (RG2) } & $\mathrm{X} 7$ & 0.754 & \multirow{5}{*}{0.858} & \multirow{5}{*}{0.606} & \multirow{5}{*}{0.853} \\
\hline & $\mathrm{X} 8$ & 0.754 & & & \\
\hline & X9 & 0.650 & & & \\
\hline & $\mathrm{X} 10$ & 0.741 & & & \\
\hline & $\mathrm{X} 11$ & 0.789 & & & \\
\hline \multirow{5}{*}{ Risk reward mechanism (RG3) } & $\mathrm{X} 12$ & 0.767 & \multirow{5}{*}{0.848} & \multirow{5}{*}{0.634} & \multirow{5}{*}{0.856} \\
\hline & $\mathrm{X} 13$ & 0.714 & & & \\
\hline & $\mathrm{X} 14$ & 0.810 & & & \\
\hline & $\mathrm{X} 15$ & 0.802 & & & \\
\hline & $\mathrm{X} 16$ & 0.653 & & & \\
\hline \multirow{5}{*}{ Project supervision mechanism (RG4) } & $\mathrm{X} 17$ & 0.816 & \multirow{5}{*}{0.822} & \multirow{5}{*}{0.572} & \multirow{5}{*}{0.835} \\
\hline & $\mathrm{X} 18$ & 0.734 & & & \\
\hline & X19 & 0.672 & & & \\
\hline & $\mathrm{X} 20$ & 0.676 & & & \\
\hline & $\mathrm{X} 21$ & 0.741 & & & \\
\hline \multirow{5}{*}{ Project controlling right (PCR) } & $\mathrm{X} 22$ & 0.662 & \multirow{5}{*}{0.758} & \multirow{5}{*}{0.684} & \multirow{5}{*}{0.883} \\
\hline & $\mathrm{X} 23$ & 0.660 & & & \\
\hline & $\mathrm{X} 24$ & 0.751 & & & \\
\hline & $\mathrm{X} 25$ & 0.777 & & & \\
\hline & $\mathrm{X} 26$ & 0.671 & & & \\
\hline \multirow{8}{*}{ Project performance (PP) } & $\mathrm{X} 27$ & 0.777 & \multirow{8}{*}{0.926} & \multirow{8}{*}{0.582} & \multirow{8}{*}{0.914} \\
\hline & $\mathrm{X} 28$ & 0.680 & & & \\
\hline & $\mathrm{X} 29$ & 0.757 & & & \\
\hline & X30 & 0.784 & & & \\
\hline & X31 & 0.741 & & & \\
\hline & X32 & 0.762 & & & \\
\hline & X33 & 0.806 & & & \\
\hline & X34 & 0.770 & & & \\
\hline
\end{tabular}

can be compared and improved repeatedly. In this study, a total of 456 questionnaires were distributed. After deleting the returned records with missing data, 393 valid questionnaires were selected as the sample, with a valid response rate of $86.18 \%$. After deleting records with missing data, 109 valid records were selected as the sample, with a valid response rate of $21.8 \%$.

From a regional perspective, the respondents in this study were mainly from Jiangxi province, Hunan province, Hubei province, Chongqing City, Sichuan province, and other regions. From the educational background, $92.11 \%$ of the respondents were undergraduate and above. According to the years of the respondents engaged in PPP project research/practice, $31.55 \%$ of the respondents were more than 5 years, $32.82 \%$ were $3-5$ years, $27.3 \%$ were $1-3$ years, $8.27 \%$ were less than 1 year. From the number of respondents involved in PPP projects, 10 or more accounted for $11.45 \%$, 6-10 accounted for $21.88 \%, 3-5$ accounted for $57.5 \%$, and 3 below accounted for $9.17 \%$. Also, respondents were employed in private sectors (36.89\%), consultancies (23.66), public organizations (29\%), and other organizations (10.45) such as nonprofit organizations and law firms. Overall, the respondents have solid professional knowledge and rich working experience in the field of public rental housing construction, which ensures the reliability of the data.

\section{Results}

5.1. Reliability and Validity Analysis. In order to evaluate the reliability of the measured data, Cronbach's alpha coefficient is used as a measure of reliability, and SPSS 20.0 software is used to test the data collected through the questionnaire survey. The test results are shown in Table 2. In Table 2, Cronbach's alpha value of all latent variables were more than the 0.8 benchmark, which indicates that the measurements have good consistency and reliability.

The validity analysis of the questionnaire mainly involves three types: content validity, discriminant validity, and convergent validity. Since the content of the scales is based on the existing mature scales and has been carefully analysed and repeatedly discussed by experts, it can be considered that the content validity is good. In Table 2, all the Kaiser-Meyer-Olkin (KMO) values were above the 0.7 benchmark. All approximate chi-square values of the 
Table 3: Standardized path coefficient.

\begin{tabular}{lcccc}
\hline Path & Estimate & S.E. & Est./SE & $P$ value \\
\hline $\mathrm{PCR} \longrightarrow \mathrm{PP}$ & 0.654 & 0.050 & 13.012 & 0.000 \\
$\mathrm{RG} \longrightarrow \mathrm{PP}$ & 0.398 & 0.056 & 7.135 & 0.000 \\
\hline
\end{tabular}

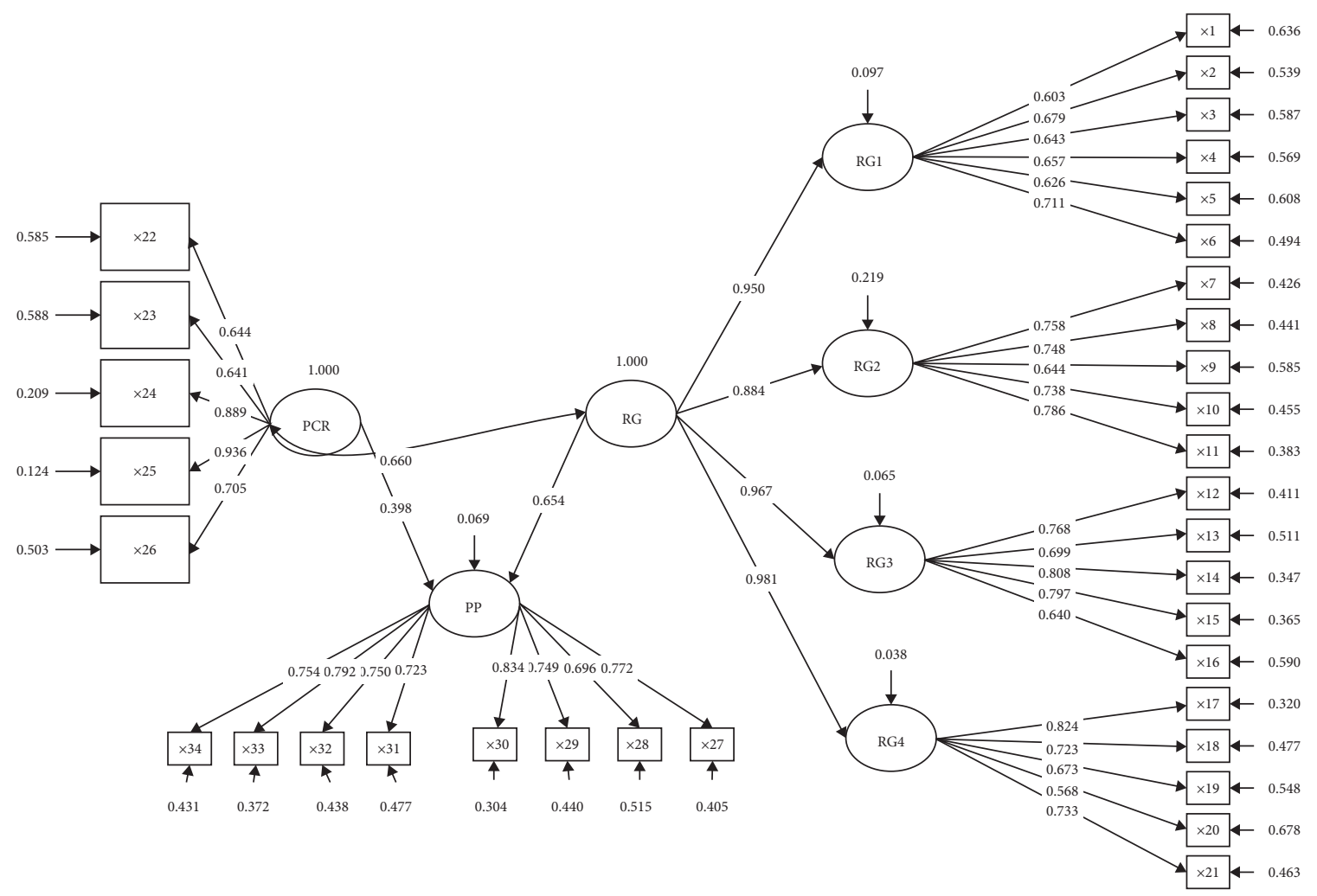

FIGURE 3: The impact of rule governance and project control on project performance.

Bartlett sphere test were larger, and all $P$ values were less than 0.001 . The values of the three indices indicate that the results pass the validity test and are suitable for factor analysis. From the perspective of convergence validity, it can be seen from Table 2 that the standard factor loading (SFL) of each measurement item is all more than 0.6 and significant at the significance level of $5 \%$, The average variance extracted (AVE) value for every variable was above the 0.5 cut-off. The values of these indices indicate the good convergent validity of all latent variables.

5.2. Confirmatory Factor Analysis without considering the Moderating Effect of Control Rights. First of all, we did not consider the adjustment effect of project control rights. The interaction items between the rule governance mechanism and the allocation of project control rights were not included in the structural equation model, and the structural equation model was used for confirmatory factor analysis of the impact of the rule governance mechanism and the allocation of project control rights on project performance. This study used Mplus8 software to fit the designed structural equation model. The results of the theoretical model fit of rule governance mechanism, project control rights, and project management performance are shown in Figure 3. Table 3 shows the standard path coefficient and significance level of the model. The results showed that the rule governance mechanism and project control rights had a significant positive impact on project performance $\left(\beta_{1}=0.654, \beta_{2}=\right.$ $0.398, p<0.001)$. Hence, both Hypothesis 1 and Hypothesis 2 were supported.

5.3. Confirmatory Factor Analysis considering the Regulating Effect of Control Rights. Furthermore, we incorporate the interaction between rule governance mechanism and project control right into the structural equation model and use LMS method to analyse the moderating effect of project control right. The partial fitting standard indexes of the original model fitting results did not meet the requirements. The model was adjusted and optimized. As is shown in Table 4 , the ratio of $\chi^{2}$ /degrees of freedom (Df) was 1.765 , which is located in the range from 1 to 2 . The root mean square error of approximation (RMSEA) value was 0.059, below the threshold level of 0.1. Furthermore, the values of GFI, AGFI, and CFI were all over the threshold level of 0.9. 
TABle 4: Results of goodness-of-fit (GOF) measures.

\begin{tabular}{lcccc}
\hline Goodness-of-fit measures & Recommended level of GOF measure & Original model & Revised model & Goodness-of-fit measures \\
\hline$\chi^{2} / \mathrm{df}$ & $<2$ & 2.346 & 1.765 & $\chi 2 / \mathrm{df}$ \\
RMR & $<0.05$ & 0.032 & 0.019 & RMR \\
RMSEA & $<0.05$ & 0.059 & 0.032 & RMSEA \\
GFI & $>0.9$ & 0.772 & 0.930 & GFI \\
AGFI & $>0.9$ & 0.742 & 0.919 & AGFI \\
PGFI & $>0.5$ & 0.682 & 0.786 & PGFI \\
CFI & $>0.9$ & 0.907 & 0.949 & CFI \\
\hline
\end{tabular}

TABLE 5: Standardized path coefficient.

\begin{tabular}{lcccc}
\hline Path & Estimate & S.E. & Est./S.E. & $P$-value \\
\hline $\mathrm{RG} \longrightarrow \mathrm{PP}$ & 0.641 & 0.051 & 12.616 & 0.000 \\
$\mathrm{CR} \longrightarrow \mathrm{PP}$ & 0.410 & 0.056 & 7.334 & 0.000 \\
$\mathrm{RG} \times \mathrm{CR} \longrightarrow \mathrm{PP}$ & -0.043 & 0.011 & -3.588 & 0.000 \\
\hline
\end{tabular}

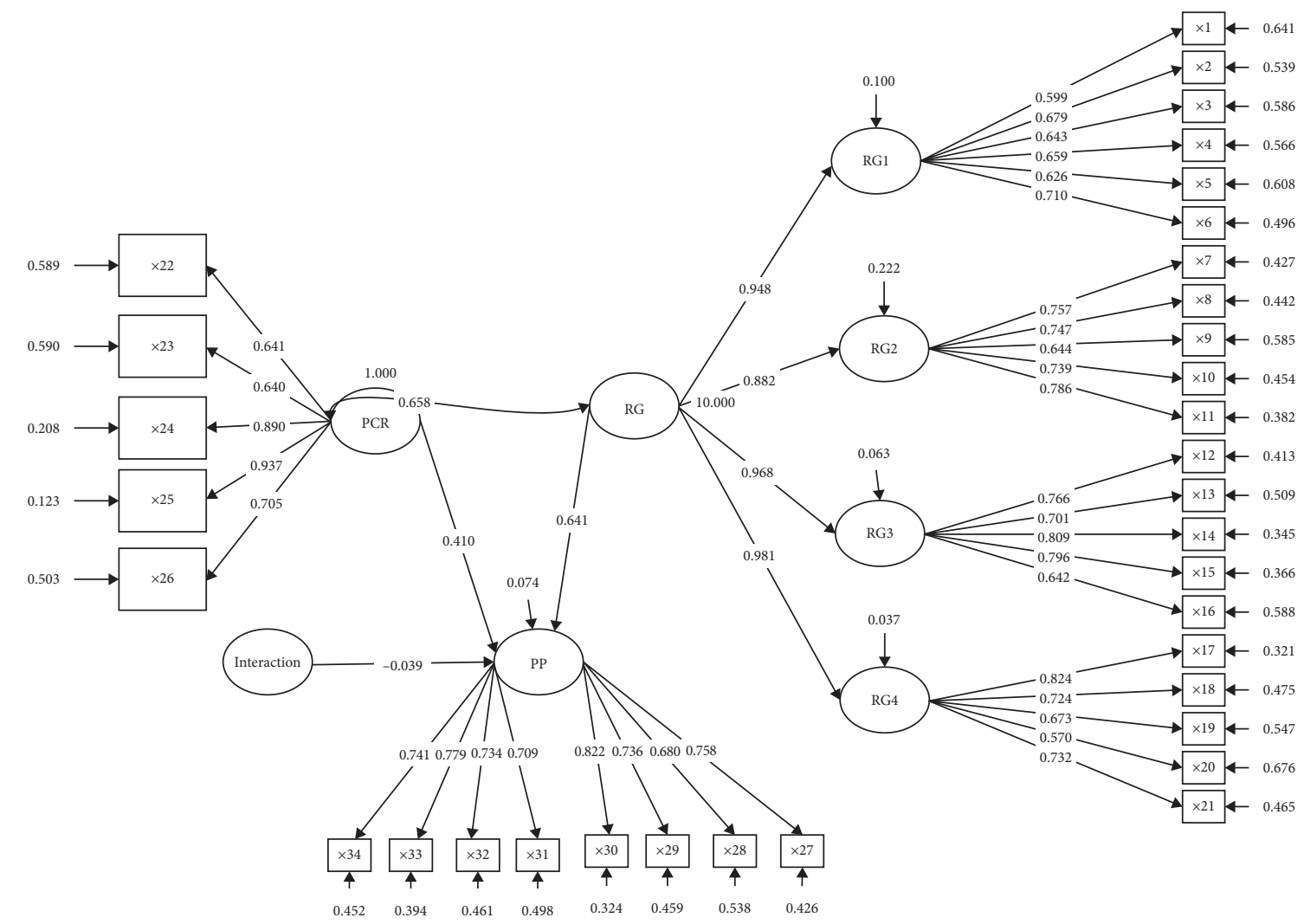

FigURE 4: Impact of rule governance on project performance under the moderating effect of project control allocation.

Thus, the GOF level of the model was acceptable. The final structural equation model is shown in Figure 4. This model tested the overall moderating effect of project control right on the impact of rule governance mechanism on project performance. Table 5 shows the standardized path coefficient and significance level of the regulatory effect analysis model. In Figure 4 and Table 5, the standardized path coefficient of rule governance mechanism and project control right on project performance is still positive. However, the standardized path coefficient of the interaction between project control right and rule governance mechanism on project performance is -0.043 , and it has passed the significance test at the $1 \%$ level. It indicated that the allocation of project control rights had a negative moderating effect on the impact of rule governance mechanism on project performance. Therefore, the hypothesis $\mathrm{H} 2$ was not valid.

\section{Conclusion and Discussion}

The empirical results show that project control has a negative moderating effect on the impact of rule governance mechanism on project performance. It is generally believed 
that reasonable allocation of project control rights can improve the positive effect of rule governance mechanism on project performance, but this view is not supported by empirical evidence. This means that giving more control rights to social capital does not necessarily improve the positive effect of the rule governance mechanism on project performance. On the contrary, it may challenge the formal rule governance mechanism and affect the impact of the rule governance mechanism on project performance. This may be explained from the following points.

First of all, from the perspective of project decisionmaking stage, social capital is prone to efficiency leakage caused by unscientific use of decision-making power in reality [49]. The empirical results show that the allocation of project control right has a negative moderating effect on the impact of project bidding mechanism on project performance, which means that the introduction of social capital in the early stage of the project is difficult to improve the efficiency of project decision-making [49]. Generally speaking, the government leads the preliminary work of PPP projects, and the risks arising from the preliminary work are basically borne by the government. Therefore, it is very important to improve the efficiency of the exercise of government control [50]. On the one hand, having sufficient information is the basis for making high-quality decisions. In the project approval stage, the government can obtain more information than social capital. For example, the housing management department has information on the structure of regional housing supply, and the civil affairs department has information on the income structure of local residents. Only the government can access the internal data of various departments, and social capital cannot master enough information on its own. Therefore, the government should control the decisionmaking power of the project in the early stage of the project [49]. On the other hand, public rental housing is related to the public interest, which will have higher quality requirements for any decision made by the government [49]. According to the research, in the early stage of the project, it is an effective way to improve the efficiency of the use of government control right to construct a reasonable participation mechanism for tenants and guide them to participate in the decision-making management of public rental housing [51,52]. For example, the project site selection determines the effect of public rental housing to a large extent. Under the existing institutional arrangements, the government only focuses on the completion of the higher-level social housing construction tasks and the number of housing units provided as the government's political performance, which determines the housing location. Insufficient attention is paid to the convenience of life of the guarantee objects, and they do not have enough information to make high-quality decisions. Therefore, in the project preparation stage, after the guarantee scope is determined, the government can choose the "Opinion Questionnaire" to investigate the demand preference of the security object, determine the demand level of the guarantee object, and then make a comprehensive decision combining with the land use of the public rental housing construction in the region, which can greatly improve the scientificity of the decision-making result.
Second, from the perspective of social capital selection stage, granting too much authority to social capital will affect the fairness and competitiveness of bidding, and thus the efficiency of the bidding mechanism. The selection of social capital for public rental housing PPP projects should follow the rules of open and fair competition, and the selection of social capital can be better achieved through the establishment and realization of a complete bidding mechanism [49,52]. As long as the bidding mechanism is perfect and market-oriented fair and open competition is implemented, more suitable social capital can be screened out, which is conducive to the improvement of project performance. Giving too much authority to social capital interferes with the fairness and competitiveness of the bidding mechanism [49], which in turn affects the efficiency of resource allocation and project performance.

Thirdly, from the internal relationship between the allocation of control rights and the risk reward mechanism of public rental housing PPP projects, the risk reward mechanism determines the distribution of interests and responsibilities of all parties in PPP projects and has a direct impact on the success of the project. In the PPP project of public rental housing, if social capital is given a larger income right, it is also necessary to make social capital bear greater risks accordingly $[42,53]$. In order to cope with risks and ensure the smooth progress of the project, social capital also needs to have greater project control rights in terms of management right and assignment right [54]. This means that social capital has greater stock appreciation right, withdrawal rights, and management rights. Public rental housing PPP projects have obvious public welfare and externalities. However, in a market economy, it is difficult to ensure that the performance of public rental housing projects does not deviate from the public welfare with the characteristics of social capital "economically rational people." In PPP projects, the principle of matching risks and benefits, the principle of benefit sharing, and the principle of risk sharing should be followed. The adoption of different returns mechanisms will inevitably correspond to different risk sharing mechanisms, which need different control rights allocations [55]. In PPP projects of public rental housing, the allocation of project control should not simply give more project control to social capital or the government but should be in line with the balanced allocation of risk and reward.

Fourth, from the perspective of the supervision of the construction and operation of public rental housing PPP projects, the public welfare and externality of public rental housing determine that its smooth implementation cannot be separated from the supervision and control of the government [49]. The project supervision mechanism aims to effectively inhibit the opportunistic behaviors of social capital and rent-seeking behavior of government administrators and improve the exercise efficiency of project control power [56]. However, the supervision mechanism of the government depends on the control right of PPP projects. Giving social capital more project control rights will weaken the government's supervision ability to a certain extent and also need to pay more supervision costs. 
Finally, it is worth mentioning that although project control has a negative moderating effect on the impact of rule governance on project performance, it does not mean that the control right of social capital can be restricted accordingly [55]. Because giving more project control rights to social capital has a negative effect on the rule governance mechanism affecting project performance, and it cannot be directly reversed that restricting the project control right of social capital will have a positive effect on the rule governance mechanism influencing project performance. In reality, different public rental housing PPP projects have different characteristics, and their rule governance mechanisms are also different [57]. The allocation of project control rights should be determined and adjusted according to the actual situation of public rental housing PPP projects and the rule governance system. The degree of project control rights owned by social capital should be balanced with the rule governance in the dynamic management process.

\section{Data Availability}

All the data used to support the findings of the study are available from the corresponding author upon request.

\section{Conflicts of Interest}

The authors declare that they have no conflicts of interest.

\section{Acknowledgments}

This paper was supported by the National Social Science Foundation of China (15BJY050) and "Research on Operation Mechanism and Contract Governance of Public Private Partnership in Public Rental Housing Construction in China."

\section{References}

[1] E. O. Ibem and E. B. Aduwo, "Assessment of residential satisfaction in public housing in Ogun State, Nigeria," Habitat International, vol. 40, pp. 163-175, 2013.

[2] M. Riazi and A. Emami, "Residential satisfaction in affordable housing: a mixed method study," Cities, vol. 82, pp. 1-9, 2018.

[3] Y. Zan and C. Jie, "Housing affordability and housing policy in Urban China," in Springerbriefs in EconomicsSpringer, Berlin, Germany, 2014.

[4] S. Liu and T. Xu, "American society of civil engineers 2014 international conference on construction and real estate management-Kunming, China (september 27-28, 2014) ICCREM 2014-a mode of public rental housing based on BTO-MBS financing," in Proceedings of the International Conference on Construction \& Real Estate Management, pp. 1278-1285, Kunming, China, September 2014.

[5] O. B. Adegun and A. A. Taiwo, "Contribution and challenges of the private sector's participation in housing in Nigeria: case study of Akure, Ondo state," Journal of Housing and The Built Environment, vol. 26, no. 4, pp. 457-467, 2011.

[6] A. Propersi, G. Mastrilli, and S. Gundes, "The third sector and social housing in Italy case study of a profit and non-profit public private partnership," in Proceedings of the 10th International Conference ISTR, Siena, Italy, July 10-13, 2012.
[7] L. I. Bing, A. Akintoye, P. J. Edwards, C. Hardcastle et al., "Critical success factors for PPP/PFI projects in the UK construction industry," Construction Management and Economics, vol. 23, no. 5, pp. 459-471, 2005.

[8] J. Liu, R. Gao, C. Y. J. Cheah, and J. Luo, "Incentive mechanism for inhibiting investors' opportunistic behavior in PPP projects," International Journal of Project Management, vol. 34, no. 7, pp. 1102-1111, 2016.

[9] X. G. Li, S. Y. Hao, and X. Ren, "Empirical research on the influences of relationship governance to the PPP project control rights," Journal of Beijing Institute of Technology (Social Sciences Edition), vol. 20, no. 03, pp. 52-59, 2018.

[10] O. E. Williamson, "The theory of the firm as governance structure: from choice to contract," Journal of Economic Perspectives, vol. 16, no. 3, pp. 171-195, 2002.

[11] C. Benítez-Ávila, A. Hartmann, G. Dewulf, and J. Henseler, "Interplay of relational and contractual governance in publicprivate partnerships: the mediating role of relational norms, trust and partners' contribution," International Journal of Project Management, vol. 36, no. 3, pp. 429-443, 2018.

[12] W. Xiong, B. Chen, H. Wang, and D. Zhu, "Governing publicprivate partnerships: a systematic review of case study literature," Australian Journal of Public Administration, vol. 78, no. 1, pp. 95-112, 2019.

[13] H. Demsetz, "Why regulate utilities?" The Journal of Law and Economics, vol. 11, no. 1, pp. 55-65, 1968.

[14] Y. Ke, S. Wang, and A. P. C. Chan, "Risk misallocation in public-private partnership projects in China," International Public Management Journal, vol. 16, no. 3, pp. 438-460, 2013.

[15] L. Bing, A. Akintoye, P. J. Edwards, and C. Hardcastle, "The allocation of risk in PPP/PFI construction projects in the UK," International Journal of Project Management, vol. 23, no. 1, pp. 25-35, 2005.

[16] Ministry of Finance of the People's Republic of China, Government and Social Capital Cooperation Model Operation Guide, Beijing, China, 2014.

[17] Ministry of Finance of the People's Republic of China, Administrative Measures for Government Procurement of Government and Social Capital Cooperation Projects, Beijing, China, 2014.

[18] O. Hart and J. Moore, "Property rights and the nature of the firm," Journal of Political Economy, vol. 98, no. 6, pp. 1119-1158, 1990.

[19] S. J. Grossman and O. Hart, "The costs and benefits of ownership: a theory of vertical and lateral integration," Journal of Political Economy, vol. 94, no. 4, pp. 691-719, 1986.

[20] M. Faccio and L. H. P. Lang, "The ultimate ownership of western european corporations," Journal of Financial Economics, vol. 65, no. 3, pp. 365-395, 2002.

[21] Ministry of Finance of the People's Republic of China, The Notice to Facilitate the Investments, Construction, and Operation of Public Rental Housing by Using PPP, Beijing, China, 2015, https://www.gov.cn/xinwen/2015-5/22/content_ 2866839.htm.

[22] H. Sun, Y. Wang, and S. Liu, "Allocation of residual control rights of a public-private partnership project based on 2-tuple linguistic model," KSCE Journal of Civil Engineering, vol. 22, no. 11, pp. 4230-4239, 2018.

[23] Y. Zhang, J. Feng, X. Song, and Z. Ke, "An optimal allocation model of residual control rights in the hydraulic PPP project," in Proceedings of the 2016 International Conference on Civil, Building and Environmental Engineering, Guangzhou, China, March 2016. 
[24] D. W. Deng, Research on the Tripartite Cooperation Model of Urban Affordable Housing, Tongji University Press, Chongqing, China, 2015, in Chinese.

[25] D. N. Chorafas, Principles of Corporate Governance, Palgrave Macmillan UK, London, UK, 2004.

[26] H. J. Bernardin and R. E. Beatty, Performance Appraisal: Assessing Human Behavior at Work, Kent Publishers, Boston, MA, USA, 1984.

[27] C. J. Heinrich, "Outcomes-based performance management in the public sector: implications for government accountability and effectiveness," Public Administration Review, vol. 62, no. 6, pp. 712-725, 2002.

[28] M. E. Katzell, Productivity, the Measure and the Myth, AMACOM, New York, NY, USA, 1975.

[29] P. Cappelli and A. Tavis, "The performance management revolution," Harvard Business Review, vol. 94, no. 10, pp. 58-67, 2016.

[30] S.-S. Leu and Y.-C. Lin, "Project performance evaluation based on statistical process control techniques," Journal of Construction Engineering and Management, vol. 134, no. 10, pp. 813-819, 2008.

[31] M. Kagioglou, R. Cooper, and G. Aouad, "Performance management in construction: a conceptual framework," Construction Management and Economics, vol. 19, no. 1, pp. 85-95, 2001.

[32] J. Yuan, W. Li, B. Xia, Y. Chen, and M. J. Skibniewski, "Operation performance measurement of public rental housing delivery by ppps with fuzzy-ahp comprehensive evaluation," International Journal of Strategic Property Management, vol. 23, no. 5, pp. 328-353, 2019.

[33] M. A. Lewis and J. K. Roehrich, "Contracts, relationships and integration: towards a model of the procurement of complex performance," International Journal of Procurement Management, vol. 2, no. 2, pp. 125-142, 2009.

[34] Z. Cao and F. Lumineau, "Revisiting the interplay between contractual and relational governance: a qualitative and metaanalytic investigation," Journal of Operations Management, vol. 33-34, no. 1, pp. 15-42, 2015.

[35] D. Malhotra, "When contracts destroy trust," Harvard Business Review, vol. 87, no. 5, p. 26, 2009.

[36] W. I. Geyskens, "The formation of buyer-supplier relationships: detailed contract drafting and close partner selection," Journal of Marketing, vol. 69, no. 4, pp. 103-117, 2005.

[37] Z. Zhang, M. Jia, and D. Wan, "Allocation of control rights and cooperation efficiency in public-private partnerships: theory and evidence from the Chinese pharmaceutical industry," International Journal of Health Care Finance and Economics, vol. 9, no. 2, pp. 169-182, 2009.

[38] X. Zhang, "Critical success factors for public-private partnerships in infrastructure development," Journal of Construction Engineering and Management, vol. 131, no. 1, pp. 3-14, 2005.

[39] A. F. M. Salman, M. J. Skibniewski, and I. Basha, "Bot viability model for large-scale infrastructure projects," Journal of Construction Engineering and Management, vol. 133, no. 1, pp. 50-63, 2007.

[40] T. Besley and M. Ghatak, "Government versus private ownership of public goods," Quarterly Journal of Economics, vol. 116, no. 4, pp. 1343-1372, 2001.

[41] M. Francesconi and A. Muthoo, "Control rights in publicprivate partnerships," Social Science Electronic Publishing, vol. 2, no. 1, pp. 26-27, 2006.
[42] A. B. Alonso-Conde, C. Brown, and J. Rojo-Suarez, "Public private partnerships: incentives, risk transfer and real options," Review of Financial Economics, vol. 16, no. 4, pp. 335-349, 2007.

[43] Y. Zhang, J. Feng, and S. Yang, "Allocation of control rights in the ppp project: a cooperative game model," Iop Conference, vol. 69, no. 1, Article ID 012075, 2017.

[44] K. C. Lam, D. Wang, P. T. K. Lee, and Y. T. Tsang, "Modelling risk allocation decision in construction contracts," International Journal of Project Management, vol. 25, no. 5, pp. 485-493, 2007.

[45] J.-H. Cheng and M.-C. Chen, "Influence of institutional and moral orientations on relational risk management in supply chains," Journal of Purchasing and Supply Management, vol. 22, no. 2, pp. 110-119, 2016.

[46] R. M. Baron and D. A. Kenny, "The moderator-mediator variable distinction in social psychological research: conceptual, strategic, and statistical considerations," Journal of Personality and Social Psychology, vol. 51, no. 6, pp. 11731182, 1986.

[47] H. W. Marsh, Z. Wen, B. Nagengast, and K. T. Hau, Structural Equation Models of Latent Interactions, Guilford Press, New York, NY, USA, 2012.

[48] R. B. Kline and T. D. Little, Principles and Practice of Structural Equation Modelling, Guilford Press, New York, NY, USA, 2011.

[49] N. Kavishe, I. Jefferson, and N. Chileshe, "An analysis of the delivery challenges influencing public-private partnership in housing projects," Engineering, Construction and Architectural Management, vol. 25, no. 2, pp. 202-240, 2018.

[50] Y. Yang, Y. Hou, and Y. Wang, "On the development of public-private partnerships in transitional economies: an explanatory framework," Public Administration Review, vol. 73, no. 2, pp. 301-310, 2013.

[51] C. Chen, M. Hubbard, and C. S. Liao, When Public-Private Partnerships Fail Analysing Citizen Engagement in PublicPrivate Partnerships-Cases from Taiwan and China, Springer Fachmedien Wiesbaden, New York, NY, USA, 2013.

[52] T. E. Kwofie, S. Afram, and E. Botchway, "A critical success model for PPP public housing delivery in Ghana," Built Environment Project \& Asset Management, vol. 6, no. 1, pp. 58-73, 2015.

[53] S. Zhang, S. Zhang, G. Ying, and X. Ding, "Contractual governance: effects of risk allocation on contractors' cooperative behavior in construction projects," Journal of Construction Engineering and Management, vol. 142, no. 6, 2016.

[54] Y. Ke and S. Wang, Franchise Project Financing (PPP)-Risk Sharing Management, " Tsinghua University Press, Beijing, China, 2011, in Chinese.

[55] L. Y. Shen, H. Li, and Q. M. Li, "Alternative concession model for build operate transfer contract projects," Journal of Construction Engineering and Management, vol. 128, no. 4, pp. 326-330, 2002.

[56] J. Forrer, J. E. Kee, K. E. Newcomer, and E. Boyer, "Publicprivate partnerships and the public accountability question," Public Administration Review, vol. 70, no. 3, pp. 475-484, 2010.

[57] T. Liu, A. Chan, and S. Q. Wang, "PPP Framework for Public Rental Housing Projects in China," in Proceedings of the 2014 International Conference on Construction and Real Estate Management, pp. 573-581, Kunming, China, September 2014. 